
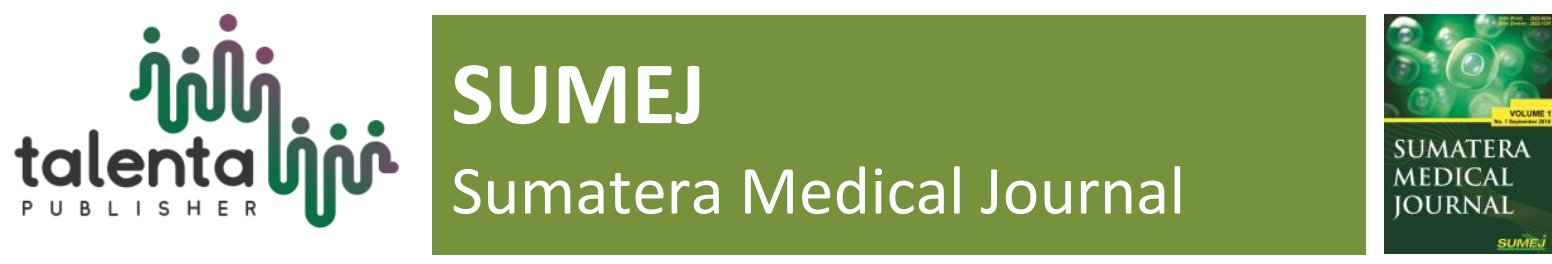

\title{
Relationship of HbA1c to Diabetic Retinopathy in Type 2 DM Patients at Haji Adam Malik General Hospital 2017- 2018
}

\author{
Yuni Ruth Artha Silalahi ${ }^{1}$, Ricke Loesnihari ${ }^{2}$ \\ ${ }^{1}$ Students of Medical Education Study Program, Medical Faculty, University of North Sumatra \\ ${ }^{2}$ Department of Clinical Pathology, Faculty of Medicine, University of North Sumatra
}

\begin{abstract}
Diabetic retinopathy is a microvascular complication of diabetes mellitus. This complication can occur due to hyperglycemia that occurs in blood vessels for a long period of time. To determine whether there is a relationship between HbA1c levels on the incidence of diabetic retinopathy on pationts with type 2 diabetes mellitus in Haji Adam Malik General Hospital Medan period of 2017 until 2018. This research is an analitical study with retrospective method (case control) and conducted at the General Hospital of Haji Adam Malik Medan. Data collection was performed on medical records of diabetic retinopathy patients at Haji Adam Malik General Hospital Medan in the period January 2017 to December 2018. Data were collected by using medial records of patients with simple random sampling technique with a total sample is 46 samples, 23 samples of diabetic retinopathy, and 23 samples that were not diabetic retinopathy. The results of this study indicate that of 23 diabetic retinopathy samples, 2 of them had controlled HbA1c and the other 21 are not controlled. As well as of the 23 samples were not diabetic retinopathy, 5 of them had $\mathrm{HbA} 1 \mathrm{c}$ controlled $\mathrm{HbA} 1 \mathrm{c}$ and 18 were uncontrolled. The result of the analysis with chi square test showed no relationship between $\mathrm{HbA1c}$ levels to the incidemce of diabetic retinopathy in Type $2 \mathrm{DM}$ patients with a $p$ value of 0,06 . From this study it was found that there was no relationship between $\mathrm{HbA1c}$ levels and the incidence of diabetic retinopathy for Haji Adam Malik General Hospital in the 2017-2018 period.
\end{abstract}

Keyword: Diabetic Retinopathy, DMT2, HbA1c, Relationship

${ }^{*}$ Corresponding author at: Faculty of Medicine, Universitas Sumatera Utara, Medan, Indonesia

E-mail address: yruthas99@gmail.com 


\section{Introduction}

Diabetes mellitus is a group of metabolic diseases with character that is hyperglycemic which occurs due to abnormal working insulin, insulin secretion or both[1]. In 2012, there were 1.5 million deaths worldwide due to diabetes. Meanwhile, in 2014, there were 422 million diabetics, and data obtained that diabetics increased from year to year in the last 3 decades[2]. The International Diabetes Federation (IDF) states that the prevalence of Diabetes Mellitus in the world is $1.9 \%$ and makes DM as the number seven cause of death in the world in 2012. DM is still a global health issue due to its increase every year[3]. According to WHO 2016, DM sufferers increased from around 180 million in 1980 to 422 million in 2012[2]. Based on IDF 2017, there are 451 million (aged 18-99 years) diabetics worldwide, and are expected to increase to 693 million by $2045[3]$.

Based on data obtained from the Riskesdas Results (2018) according to the diagnosis results of doctors at all ages, it was found that the regions that suffered the most from DM were DKI Jakarta $(2.6 \%)$ followed by DI Yogyakarta $(2.4 \%)$ and North Sulawesi $(2,3 \%)$ in the third position. The area with the least population suffering from DM is East Nusa Tenggara (0.6\%). The prevalence of DM sufferers in North Sumatra is $1.4 \%$ [4].

One of the clinical symptoms of type 2 diabetes mellitus is hyperglycemia, which is caused by insulin resistance. And due to increased glucose levels in the blood, can cause retinopathy. Diabetic retinopathy (RD) can cause blindness and is a major cause of blindness of the productive age, of 3 patients with DM can get 1 patient with RD, and 1 in 10 can be threatened with blindness[5]. In America, about 28.5-40.3\% of patients with type 2 diabetes suffer from RD. Most countries in Asia report that the prevalence of RD is around 12.1-23.0\%. Malaysia and India are reported to have a high RD prevalence, where 33.4\% occurrences are in Malaysia, and $33.0 \%$ in India, compared to China which has a prevalence of $25.4 \%$. In the Middle East, namely Saudi Arabia and Iran, the prevalence of RD is almost the same as the West (36.8 and $29.6 \%$, respectively). This study shows that most cases of diabetic retinopathy are diagnosed for long periods of time, ie when there has been progression in visual impairment, or are susceptible to experiencing RD due to ethnic or ethnic influences[6].

In Indonesia alone the data obtained by Basic Health Research (Riskesdas) in 2013, the prevalence of $\mathrm{RD}$ is $33.4 \%$ and is the second most complications in DM patients treated at RSCM in 2011[4]. According to the 2014 Non-communicable Disease Survailans Data of the South Sulawesi Provincial Health Office in 2014, DM disease with 27,470 new cases and 66,780 old cases with 747 deaths[5]. From the results of research conducted by Mursi et al (2018), 54 patients with diabetic retinopathy were obtained from the medical records of RSUP Dr. M. Djamil Padang for the period of January- December 2015[1]. Research by Ridhani (2018) conducted at Dr. Soetomo Surabaya in the period January 2016- December 2017 found 40 patients with diabetic retinopathy, with a greater prevalence in men than women[7]. 
One of the main factors causing Diabetic Retinopathy is hyperglycemia, and the HbA1c examination is thought to be the best test to assess blood glucose levels during the last 3 months. There is a relationship between HbA1c levels and severity of diabetic retinopathy. In a study conducted by S. Refa and NA Dewi (2005), with a cutoff of $8.147 \%$, it showed that diabetics could fall in the direction of severe diabetic retinopathy[8]. A study revealed, the examination of $\mathrm{HbA1c}$ as a strong biomarker for laser treatment needs. The prevalence of patients receiving laser treatment, that is, treatment with an indication of PDR, increased sharply with increasing HbA1c levels, in the group with HbA1c> 9.5\%[9].

The high incidence of diabetic retinopathy in Indonesia has caused researchers to be interested in conducting further research on the relationship of HbAlc to the incidence of diabetic retinopathy specifically in patients with Type 2 Diabetes Mellitus.

\section{Method}

This study was conducted using an observational (non-experimental) analytic research design using a cross sectional approach. In this study, we want to know the relationship between HbA1c leveels and diabetic retinopathy in patients with type 2 diabetes mellitus from 2017 to 2018 in Haji Adam Malik General Hospital Medan.

Data that has been collected and grouped according to variables will then be processed and analyzed using the SPSS (Statistical Packate for Social Science) program. These data will then be presented in the form of frequency distribution tables. Data analysis method will be performed using the chi square method.

\section{Result}

\section{Sample Characteristics}

Table 1. shows samples that suffer from diabetic retinopathy and those that are not the same are 23 samples (50\%), because this study uses the method $n 1=n 2$. Based on age, it is found that the age group of 40-60 years is the most, as many as 25 samples (54.3\%) followed by age $>60$ years as many as 20 samples (43.5\%), and the least is the age of $<40$ years $(2,2 \%)$. Based on gender, there were 27 male samples (58.7\%), and 19 female samples (41.3\%). 
Table 1. Characteristics of Sample

\begin{tabular}{|c|c|c|}
\hline Variables & Frequency $(n=56)$ & Persentage (\%) \\
\hline \multicolumn{3}{|l|}{ Diabetic Retinopathy } \\
\hline Yes & 23 & 9 \\
\hline No & 23 & 41,1 \\
\hline \multicolumn{3}{|l|}{ Gender } \\
\hline Male & 27 & 58,7 \\
\hline Female & 19 & 41,3 \\
\hline \multicolumn{3}{|l|}{ Age } \\
\hline$<40$ years & 1 & 2,2 \\
\hline $40-60$ years & 25 & 54,3 \\
\hline$>60$ years & 20 & 43,5 \\
\hline \multicolumn{3}{|l|}{ Mean HbA1c } \\
\hline$<8,08$ & 30 & 65,2 \\
\hline$\geq 8,08$ & 16 & 34,8 \\
\hline \multicolumn{3}{|l|}{ Controlled } \\
\hline Yes & 14 & 30,4 \\
\hline No & 32 & 69,6 \\
\hline
\end{tabular}

\section{Relationships of Diabetic Retinopathy and HbA1c}

Table 3. shows diabetic retinopathy and HbA1c levels. In thetest results chi-square, the value used is the value on Pearson chi-square. The $p$ value obtained is 0.06 ( $p>0.05)$. This means there is no relationship between diabetic retinopathy and HbA1c.

Table 2. Relationship of Diabetic Retinopathy and HbA1c in DM Type 2 Patients

\begin{tabular}{|c|c|c|c|c|c|c|c|c|}
\hline & & \multicolumn{4}{|c|}{$\mathrm{HbA1c}$} & \multicolumn{2}{|c|}{ Total } & \multirow[t]{3}{*}{$P(\mathrm{Sig})$} \\
\hline & & \multicolumn{2}{|c|}{$<6,5 \%$} & \multicolumn{2}{|c|}{$\geq 6,5 \%$} & \multirow[b]{2}{*}{$\mathrm{N}$} & \multirow[b]{2}{*}{$\%$} & \\
\hline & & $\mathrm{n}$ & $\%$ & $\mathrm{~N}$ & $\%$ & & & \\
\hline \multirow[t]{2}{*}{$\mathrm{RD}$} & Yes & 4 & 0,09 & 19 & 0,41 & 23 & 50 & 0,06 \\
\hline & No & 10 & 0,22 & 13 & 0,28 & 23 & 50 & \\
\hline Tota & & 14 & 0,31 & 29 & 0,69 & 46 & 100 & \\
\hline
\end{tabular}




\section{Discussion}

In the Chi Square test results, the value used is the value on the Pearson Chi-Square. Statistical test results of the relationship between HbA1c and diabetic retinopathy showed a significance value of 0.06. It can be seen that the variable has an Asymptomatic Significance value $>0.05$ so statistically, the hypothesis of this study was rejected, namely HbA1c levels were not related to the incidence of diabetic retinopathy caused by type 2 diabetes mellitus.

This also occurred in research by Arisandi (2018) which get a p value of $0.098 \%$ which means there is no relationship between HbA1c levels and the incidence of diabetic retinopathy[10]. Research by Fadli (2016) also obtained the same results with $P=0.976$ which means there is no relationship between HbA1c levels and the incidence of diabetic retinopathy[11].

In contrast to research conducted by (Refa and Dewi, 2005) which found there is a relationship between $\mathrm{HbA1c}$ levels and the severity of diabetic retinopathy with $\mathrm{P}=0.017$, which also states that high levels of HbA1c will provide a greater likelihood of falling in a state of diabetic retinopathy degree of weight[8]. And also with research conducted (Valizadeh et al, 2016) which showed $\mathrm{P}=0.02$ namely there is a relationship between $\mathrm{HbA} 1 \mathrm{c}$ levels and the incidence of diabetic retinopathy conducted in Kerman, Iran[12].

\section{Conclusion}

Based on the results of data analysis and discussions that have been carried out in this study, it is concluded: in this study, obtained 7 samples with $\mathrm{HbA1c}<6.5 \%$, and 39 samples with $\mathrm{HbA} 1 \mathrm{c}$ values $\geq 6.5 \%$. In this study, 23 samples were suffered from diabetic retinopathy in the 2017 2018 period.

The results of the analysis of the relationship between $\mathrm{HbA1c}$ levels to the sample with diabetic retinopathy due to type 2 diabetes mellitus using the chi-square test, obtained a p value of 0.06. It can be hypothesized that there is no association of $\mathrm{HbAlc}$ with the incidence of diabetic retinopathy.

\section{References}

[1] Mursi, ZA, Hendriati, Isrona. L. 2018, The Relationship of LDL Cholesterol to the Degree of Diabetic Retinopathy in the Eye Section of RSUP Dr. M. Djamil Padang Period JanuaryDecember 2015, Andalas Health Journal 7 (4): 498-503

[2] WHO. 2016 Definition and Diagnosis of Diabetes Mellitus and Intermediate Hyperglycemia, Report of WHO / IDF Consultation

[3] Cho, N., Shaw, JE, Karuranga, S., Huang, Y., da Rocha Fernandes, JD, Ohlrogge, AW, Malanda, B. 2018 , IDF Diabetes Atlas: Global Estimates of Diabetes Prevalence for 2017 
and Projections for 2045, accessed 10 May 2019, Available at: https://www.diabetesresearchclinicalpractice.com/article/S0168-8277(13)00385-9/fulltext

[4] Ministry of Health Republic of Indonesia (RI Ministry of Health). 2018, RISKESDAS National Report, accessed 9 May 2019, Available from: https://www.depkes.go.id/article/view/18110200003/potret-sehat-indonesia-dari-riskesdas2018.html

[5] Nursyamsi, Muhiddin HS, Jennifer G. 2018, Knowledge of Diabetic Retinopathy Amongst Type II Diabetes Mellitus Patients in Dr. Wahidin Sudirohusodo Hospital, Nusantara Medical Science Journal 3 (2): 23-29

[6]Lee, R., Wong, TY \& Sabanayagam, C. 2015, Epidemiology of Diabetic Retinopathy, Diabetic Macular Edema and Related Vision Loss, accessed 9 May 2019, Available at: https://www.ncbi.nlm.nih.gov/pmc/articles/PMC4657234/

[7]Ridhani A. 2018, Risk Factors for the Occurrence of Diabetic Retinopathy in Eye Polyclinic Dr. Soetomo Surabaya in January 2016-December 2017, thesis, Airlangga University, Surabaya

[8]Refa, S., Dewi, NA 2005, 'Relationship between HbA1c and Serum Lipid Levels with Severe Degree of Diabetic Retinopathy', Brawijaya Medical Journal, 21 (3): 138-144

[9] Nordwall, M., Abrahamsson, M., Dhir, M., Fredikson, M., Ludvigsson, J., Amqvist, HJ 2015, 'Impact of HbA1c Followed From Onset of Type 1 Diabetes, on the Development of Severe Retinopathy and Nephropathy: The VISS Study (Vascular Diabetic Complications in Southeast Sweded), Diabetes Care, 38: 308-315

[10] Arisandi, R., Yusran, M., Mutiara, H. 2018, Relationship of HbA1c Levels with Diabetic Retinopathy Incidence Rate in Patients Type 2 Diabetes Mellitus Following Prolanis at the Kedaton Health Center in Bandar Lampung City, Lampung University Medical Journal 7 (3): 19-23

[11] Fadli, N. 2016, Relationship of HbA1c Levels to Diabetic Retinopathy in Type 2 DM Patients in Dr. Saiful Anwar Malang, Accessed 20 November 2019, Available at: https://eprints.umm.ac.id/33012

[12] Valizadeh, R., Moosazadel M., Bahaadini K., Vali L., Lashkari T., Amiresmaili M. 2016 , 'Determining the Prevalence of Retinopathy and Its Related Factors Among Patients with Type 2 Diabetes in Kerman, Iran', Republic of Korea Centers for Disease Control and Prevention, accessed 19 December 2019, Available at: http://dx.doi.org /10.1016/j.phrp.2016.08.004 